\title{
STUDY OF THE FUNCTIONAL PRODUCT'S PROTEIN COMPOUNDS DIGESTION FEATURES
}

Ekaterina R. Vasilevskaya ${ }^{\star}$, Anastasiya G. Akhremko, Ekaterina K. Polishchuk, Liliya V. Fedulova

V. M. Gorbatov Federal Research Center for Food Systems of Russian Academy of Sciences, Moscow, Russia

Keywords: digestion, biocorrecting meat product, proteins, peptides, one-dimensional electrophoresis

\begin{abstract}
The aim of the study was to investigate the transformation of meat product's proteins from pig hearts and aortas during enzymatic hydrolysis in an in vitro model of the gastrointestinal tract. The model consisted of three phases simulating digestion processes: "oral cavity" phase (a-amylase, pH 7.0; 2 min), "stomach" phase (pork pepsin, pH 3.0; 120 min), "intestine" phase (pork pancreatin, pH 7.0; $130 \mathrm{~min}$ ). The product was sequentially subjected to hydrolysis, at the end of each phase, samples were taken to determine the protein concentration (biuret method) and visualize the protein fractions (one-dimensional electrophoresis). A significant increase in protein concentration at the "stomach" phase was revealed by 3.2 times, and the absolute content by 4.6 times. At the "intestine" phase, a decrease in the number of peptide complexes with copper ions by 1.8 times, the absolute protein content by $8.5 \%$ was revealed. The noted tendency was confirmed by electrophoretic studies - at the stage, simulating digestion in the stomach, the products of meat product's proteins hydrolysis were visualized; at the "intestine" phase, a low expression of protein fractions in the range of more than $10 \mathrm{kDa}$ is shown. The maximum hydrolysis of protein compounds at the "stomach" phase to poly-and oligopeptides was confirmed, continuing at the "intestine" stage with the accumulation of free amino acids. This methodology makes it possible to visualize the products of hydrolysis of proteins in a meat product at all stages of the model and to monitor changes in protein concentration in the system.
\end{abstract}

Funding: The research was supported by state assignment of V. M. Gorbatov Federal Research Centre for Food Systems of RAS, scientific research No. 013.20.05.

\section{Introduction}

Animal food products' proteins are of particular interest today due to the fact that such compounds are the main source of biologically active components.

Today bioactive components of foods are considered dietary elements that have a measurable biological effect (for example, antioxidant, immunomodulatory, antihypertensive, osteoprotective, hypolipedemic, opiate, etc.) and have a beneficial effect on human health $[1,2,3]$. During different phases of industrial processing and digestion, bioactive peptides with a wide range of biological effects can be released from protein $[4,5]$.

It is known that bioactive peptides are naturally formed in mammals in the gastrointestinal tract during the metabolism of dietary meat proteins. Consumed proteins derived from raw meat are attacked by digestive enzymes secreted by the stomach, such as pepsin, and, in the small intestine, trypsin, chymotrypsin, elastase, and carboxypeptidase undergo proteolysis. To study peptides of meat products that potentially have functional effects, a simulated digestive system of the gastrointestinal tract can be used to reproduce the processes of generating peptides similar to those released during physiological digestion. The process that simulates digestion of the gastrointestinal tract is based on enzymatic hydrolysis using various commercial exogenous proteinases obtained from animal tissues (pepsin and trypsin), plants (papain, ficin and bromelain) and microbial sources (alkalase, collagenase or proteinase, etc.) [6,7].
The number of studies that use the methodology of modeling gastrointestinal digestion in vitro to study bioactive peptides from food proteins are increasing $[8,9,10,11,12,13]$. Using these methods, researchers are trying to isolate bioactive peptides that can be produced in our body after eating a certain food or dietary protein, and determine its activity.

In this article, we will attempt to understand meat products' proteins transformation using the example of a biocorregating product based on pigs' hearts and aorts after passing through the digestive tract.

\section{Materials and methods}

The object of the study was an experimental development - a meat product made on the basis of pig hearts and aortas in accordance with $[14,15]$, containing functional proteins with biocorregulating properties $[16,17,18]$.

The functional product is a sterilized canned minced meat, it contains $17.5 \pm 0.9 \%$ protein, $3.8 \pm 0.1 \%$ fat, $0.30 \pm 0.01 \%$ sodium chloride and $2.3 \pm 0.2 \%$ starch.

To simulate the digestion process of the experimental product, a static model of digestion was used in accordance with [19]. Pate crushed in a mortar to a particle size of $3 \pm 0.5 \mathrm{~mm}$ in amount of $10 \mathrm{~g}$ was placed in I imitating liquid ("oral cavity", $\mathrm{pH}$ 7, volume $7 \mathrm{ml}$ ), consisting of $0.5 \mathrm{ml}$ of $\alpha$-amylase (30 U/mg, "PanReac AppliChem", Germany), $25 \mu \mathrm{l}$ of calcium chloride $(0.3 \mathrm{~m}), 10.6 \mathrm{ml}$ of phosphate-salt buffer ("Sigma-Aldrich", USA) and 0.09 
$\mathrm{ml}$ of hydrochloric acid (6 M, "Sigma-Aldrich", USA). The mixture was then thoroughly mixed for 2 minutes and a sample was taken for further studies. Next, $10 \mathrm{ml}$ of the mixture was placed in II imitating liquid ("stomach", $\mathrm{pH} \mathrm{3,} \mathrm{volume} 15 \mathrm{ml}$ ), consisting of $1.6 \mathrm{ml}$ of pig pepsin solution (250 U / mg, "PanReac AppliChem", Germany), $5 \mathrm{ml}$ of calcium chloride (0.3 M, "Sigma-Aldrich", USA)), $0.8 \mathrm{ml}$ of hydrochloric acid $(1 \mathrm{M})$ and $10.0 \mathrm{ml}$ of phosphate-salt buffer. The mixture was stirred using a magnetic stirrer for 120 minutes, and samples were taken for further studies at the end of the incubation time. Then $20 \mathrm{ml}$ of gastric hummus was added to the III imitating liquid ("intestines", $\mathrm{pH} \mathrm{7}$, volume $20 \mathrm{ml}$ ) containing 5.0 $\mathrm{ml}$ of porcine Pancreatin solution (50.5 U / mg, "PanReac AppliChem", Germany), $1.5 \mathrm{ml}$ of canned bovine bile ("Samson-med", Russia) and $40 \mathrm{ml}$ of $0.3 \mathrm{M}$ calcium chloride, $10.6 \mathrm{ml}$ of phosphate-salt buffer. To neutralize the mixture of a neutral $\mathrm{pH}$ value, $0.6 \mathrm{ml}$ of $1 \mathrm{M}$ sodium hydroxide (Sigma-Aldrich, USA) and $986 \mu$ l of distilled water were added. The mixing time was 130 minutes, then samples were also taken. In parallel, similar procedures were performed for all stages of the model without adding the test sample to obtain control samples.

All samples were taken in plastic tubes of the Eppendorf type and placed in a freezer at a temperature of minus $(40 \pm 1)^{\circ} \mathrm{C}$ to inactivate the enzymatic activity for at least 60 minutes. After defrosting, the samples were centrifuged using a CM-6M centrifuge (ELMI, Latvia) at $3500 \mathrm{rpm}$ for 5 minutes.

The protein concentration in the supernatant of the samples after centrifugation was measured by biuret method in accordance with [20] on Biochem SA photometer (HTI, USA).

For electrophoretic analysis, 50,00 $\pm 0.05 \mathrm{ml}$ of the sample's supernatant was taken into a microcentrifuge tube, $50 \mu \mathrm{l}$ of solubilizing solution was added (Glycerol 10\%, $\beta$-mercaptoethanol $0.01 \mathrm{M}$, Bromphenol blue $0.02 \%$, Tris$\mathrm{HCl} 0.5 \mathrm{M}, \mathrm{SDS} 2 \%$ - "Sigma-Aldrich", USA) and kept in a thermostat at $95^{\circ} \mathrm{C}$ for 5 minutes. The resulting solution was centrifuged in an Eppendorf 5402r centrifuge at 14,000 rpm for 8 minutes. The supernatant was used for further analysis.

Analysis of the fractional composition was carried out by denaturing electrophoresis in $10 \%$ polyacrylamide gel in the presence of sodium dodecyl sulfate using a Hellicon "VE-10" electrophoretic chamber, at a constant current and voltage of $55 \mathrm{~V}$ and $130 \mathrm{~V}$, for 2 hours. As a solution of standards, a marker consisting of standard preparations with a molecular weight is used 250, 150, 100, 70, 50, 40, 30, $20 \mathrm{kDa}$ (“Thremo", Latvia). Visualization was performed with Coomassie R250 solution and silver nitric acid ("Sigma-Aldrich", USA).

\section{Results and discussion}

Proteins' biotransformation in the product was evaluated by quantifying the formation of protein peptide bonds with divalent copper ions during modeling and visualization of protein compounds after gradual digestion by digestive enzymes.

According to the study results, it was found that during modeling stage I, which recreates the conditions of product's digestion in the "oral cavity", there were no significant changes in the protein concentration (Figure 1). The main transformations were revealed after the second phase corresponding to digestion in the "stomach" - the protein concentration increased by 3.2 times, and the absolute protein content increased by 4.6 times. At stage III, after passing the simulated "intestine" fluid, the protein concentration in the system decreased by 1.8 times, but the absolute protein content decreased by only $8.5 \%$, relative to stage II.

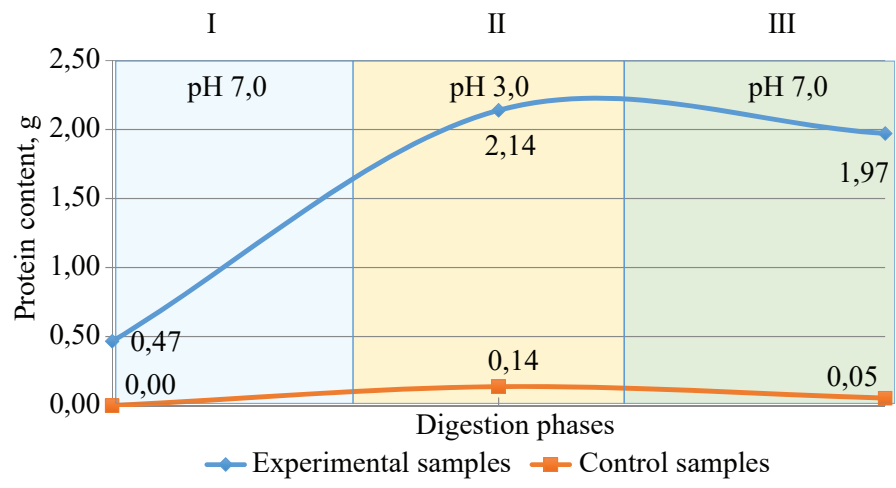

Figure 1. Protein content after digestion model phases

When one-dimensional electrophoresis was stained with Coomassie solution, the preservation of product's major fractions with molecular weights in range from 35 to $37 \mathrm{kDa}$ and $13 \mathrm{kDa}$ was shown (Figure $2 \mathrm{~A}$, track 1 ), and fractions corresponding to oral enzymes were also identified. When visualizing with silver nitrate, the presence of an almost complete spectrum of the initial product can be noted, with the addition of oral enzymes fractions (Figure 2B, track 1).

On the second track of the electrophoregram, the result of enzymatic hydrolysis of product proteins was demonstrated. Coomassie staining revealed a protein front in the range of molecular weights less than $12 \mathrm{kDa}$, which was not previously detected in the product, as well as minor fractions $(42-48 \mathrm{kDa})$ corresponding to "stomach" enzymes (Figure 2A, track 2). Nitric silver as a dye allowed us to detect the presence of protein fractions in the range of molecular weights from 250 to $80 \mathrm{kDa}$, from 40 to $25 \mathrm{kDa}$, and from 17 to $14 \mathrm{kDa}$, which correspond to the proteins initially present in the product (Figure $2 \mathrm{~B}$, track 2 ).

Similar results were found when visualizing product's protein profile at the end of the third phase of digestion ("intestine"). After Coomassie staining, low-molecular compounds (less than $12 \mathrm{kDa}$ ) and enzymatic minor bands in the molecular weight range of $28-30 \mathrm{kDa}$ were also visualized (Figure 2A, track 3 ). The dye with silver nitric acid also showed the presence of protein bands fixed in the sample obtained after the "intestine" stage (Figure 2B, tracks 2 and 3 ). 

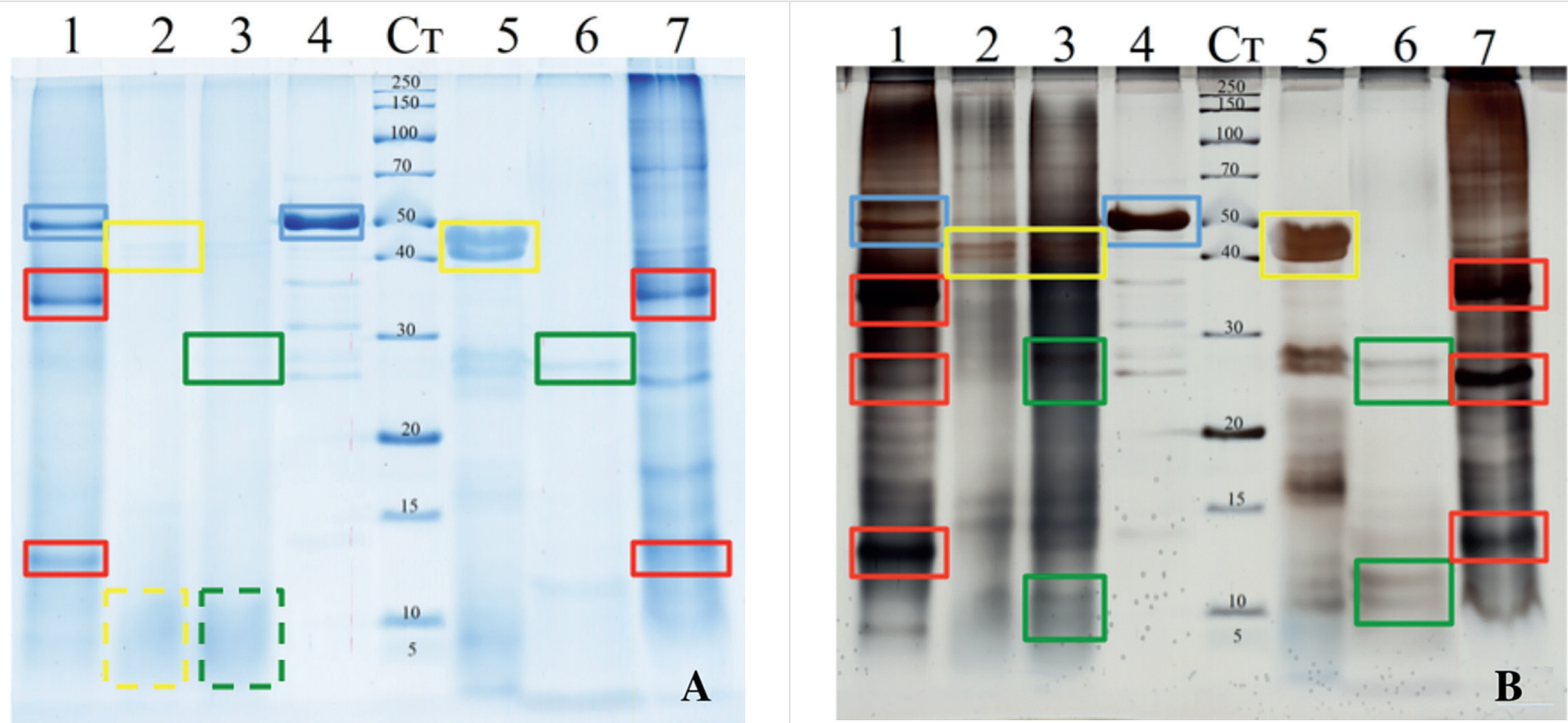

Figure 2. One-dimensional electrophoregrams of the studied samples. A - Coomassie color; B - silver nitric acid color.

Symbols:

1 - I phase - imitation of digestion in the " oral cavity»;

2 - II phase - imitation of digestion in the "stomach»;

3 - III phase - imitation of digestion in the "gut»;

4 - control sample for phase I;

The revealed tendency to decrease the concentration of protein and its absolute content is due to the fact that the "stomach" phase is active hydrolysis of product proteins by pig pepsin, which cleaves the central peptide bonds in protein molecules. At this phase, a large number of poly- and oligopeptides and a small amount of free amino acids are formed. The decrease in the number of peptide complexes with divalent copper ions at the "intestine" stage is due to the specificity of the action of trypsin and chymotrypsin, which destroy them with the formation of carboxyl groups of amino acids, as well as free amino acids [21,22].

As expected, the one-dimensional electrophoregram also visualized hydrolysis of meat product proteins at the stage simulating digestion in the stomach. When simulating digestion in the"intestine", the marked decrease in the number of peptide complexes with copper ions (by 8.5\%) correlates with a low expression of protein fractions in the
Ст — standard for molecular weights: $250,150,100,70,50,40,30$,

$20 \mathrm{kDa}$ (top to bottom)

5 - control sample for phase II;

6 - control sample for phase III;

7 - product before the experiment.

range of more than $10 \mathrm{kDa}$ and confirms the further metabolism of protein compounds - the conversion of peptides to free amino acids.

\section{Conclusion}

The prospects of using a complex technique for studying the digestibility of functional products' proteins, including a three-stage enzymatic model of digestion with sequential sampling to determine the protein concentration at each stage and visualization of individual components on onedimensional electrophoresis, were proved. The demonstrated results of the study indicate the accumulation of a peptide pool during digestion, and special attention should be paid to "stomach" and "intestine" phases.

The next step in the study of bioactive peptides obtained in the meat product proteins' proteolysis process, that can be identified, and its' absorption study at the intestinal level in the in vitro system using cell cultures.

\section{REFERENCES}

1. Bechaux, J., Gatellier, P., Le Page, J.F., Drillet, Y., SanteLhoutellier, V. (2019). A comprehensive review of bioactive peptides obtained from animal byproducts and their applications. Food and Function, 10(10), 6244-6266. https://doi. org/10.1039/c9fo01546a

2. Albenzio, M., Santillo, A., Caroprese, M., Della Malva, A., Marino, R. (2017). Bioactive Peptides in Animal Food Products. Foods, 6(5), 35. https://doi.org/10.3390/foods6050035

3. Kupaeva, N.V, Kotenkova, E.A. (2019). Analysis of the antioxidant capacity of farm animal raw materials. Vsyo o myase, 5 , 34-37. https://doi.org/10.21323/2071-2499-2019-5-34-37 (in Russuan)

4. Chernukha, I.M., Afanasyev, D.A., Mashentseva, N.G., Vostrikova, N.L. (2019). Biologically active peptides as a product of microbial fermentation of raw meat and finished meat products: review. Part 1. General information about biologically ac- tive peptides of meat and meat products. Theory and practice of meat processing, 4(4), 12-16. https://doi.org/10.21323/2414438X-2019-4-4-12-16 (in Russian)

5. Chernukha, I.M., Afanasyev, D.A., Mashentseva, N.G., Vostrikova, N.L. (2020). Biologically active peptides as a product of microbial fermentation of raw meat and finished meat products: review. Part 2 . Functionality of bioactive meat peptides. Theory and practice of meat processing, 5(2), 12-19. https://doi. org/10.21323/2414-438X-2020-5-2-12-19 (in Russian)

6. Fu, Y., Zhang, Y., Soladoye, O.P., Aluko, R.E. (2019). Maillard reaction products derived from food protein-derived peptides: insights into flavor and bioactivity. Critical reviews in food science and nutrition, 18, 1-14. https://doi.org/10.1080/10408398.20 19.1691500

7. Lafarga, T., O'Connor, P., Hayes, M. (2015). In silico methods to identify meat-derived prolyl endopeptidase inhibitors. Food 
Chemistry, 175, 337-343. https://doi.org/10.1016/j.foodchem.2014.11.150

8. Kong, F., Singh, R.P. (2010). A human gastric simulator (HGS) to study food digestion in human stomach. Journal of Food Science, 75(9), E627-E635. doi:10.1111/j.1750-3841.2010.01856.x

9. Picariello, G., Miralles, B., Mamone, G., Sánchez-Rivera, L., Recio, I., Addeo, F., Ferranti, P. (2015). Role of intestinal brush border peptidases in the simulated digestion of milk proteins. Molecular Nutrition and Food Research, 59(5), 948-956. https://doi. org/10.1002/mnfr.201400856

10. Vieira, E.F., das Neves, J., Vitorino, R., Dias da Silva, D., Carmo, H., Ferreira, I.M. (2016). Impact of in vitro Gastrointestinal Digestion and Transepithelial Transport on Antioxidant and ACE-Inhibitory Activities of Brewer's Spent Yeast Autolysate. Journal of Agricultural and Food Chemistry, 64(39), 7335-7341. https://doi.org/10.1021/acs.jafc.6b02719

11. Mora, L., Bolumar, T., Heres, A., Toldrá, F. (2017). Effect of cooking and simulated gastrointestinal digestion on the activity of generated bioactive peptides in aged beef meat. Food and Function, 8(12), 4347-4355. https://doi.org/10.1039/C7F001148B 12. Aspri, M., Leni, G., Galaverna, G., Papademas, P. (2018). Bioactive properties of fermented donkey milk, before and after in vitro simulated gastrointestinal digestion. Food Chemistry, 268, 476-484. https://doi.org/10.1016/j.foodchem.2018.06.119

13. Chakrabarti, S., Guha, S., Majumder, K. (2018). Food-Derived Bioactive Peptides in Human Health: Challenges and Opportunities. Nutrients, 10(11), 1738. https://doi.org/10.3390/ nu10111738

14. Lisitsyn, A.B., Chernukha, I.M., Fedulova, L.V., Kotenkova, E. A. Functional meat product and its manufacture method. Pathent RF, no. 2550649, 2015. (in Russian)

15. Kotenkova E. A. (2015). Application of biotechnological and proteomic methods in the development of food products with hypolipidemic and vasoprotective effects. Author's abstract of the dissertation for the scientific degree of Candidate of Technical Sciences. Moscow: VNIIMP. - 22 p. (in Russian)

16. Chernukha, I., Fedulova, L., Kotenkova, E., Akhremko, A. (2018). Hypolipidemic action of the meat product: in vivo study. Potravinarstvo Slovak Journal of Food Sciences, 12(1), 566-569. https://doi.org/10.5219/959

17. Chernukha, I.M., Kotenkova, E.A. (2018). Ifluence of functional food product on serum fatty acid composition in hyperlipidemic rats. Food systems, 1(4), 4-9. https://doi.org/10.21323/26189771-2018-1-4-4-9 (in Russian)

18. Kotenkova, E.A., Fedulova, L.V., Chernukha, I.M. (2017). The study of isolated from sus scrofa aorta tissue-specific substances with a molecular weight less than $30 \mathrm{kDa}$. Vsyo o myase, 2, 4042. (in Russian)

19. Fedulova, L.V., Vasilevskaya, E.R., Kotenkova, E.A., Kalinova, E.A. (2018). Algorithm of in vitro assessment for products containing bioactive substances. Vsyo o myase, 6, 47-49. https://doi. org/10.21323/2071-2499-2018-6-47-49. (in Russian)

20. Vasilevskaya, E.R., Kotenkova, E.A., Lukoniva, E.A., Kalinova, E.A. (2017). Research methodology of Sus Scrofa tissue extracts protein-peptide components. Theory and practice of meat processing, 2(3), 79-85. https://doi.org/10.21323/2414438X-2017-2-3-79-85 (in Russian)

21. Li, L., Liu, Y., Zhou, G., Xu, X., Li, C. (2017). Proteome Profiles of Digested Products of Commercial Meat Sources. Frontiers in Nutrition, 4, 8. https://doi.org/10.3389/fnut.2017.00008

22. Wen, S., Zhou, G., Song, S., Xu, X., VogImeir, J., Liu, L., Zhao, F., Li, M., Li, L., Yu, X., Bai, Y., Li, C. (2015). Discrimination of in vitro and in vivo digestion products of meat proteins from pork, beef, chicken, and fish. Proteomics, 15(21), 3688-3698. https://doi. org/10.1002/pmic.201500179

\section{AUTHOR INFORMATION}

Ekaterina R. Vasilevskaya - candidate of technical sciences, researcher, Experimental clinic-laboratory of biologically active substances of animal origin, V. M. Gorbatov Federal Research Center for Food Systems of Russian Academy of Sciences. 109316, Moscow, Talalikhina str., 26. Tel.: +7-495-676-92-11, E-mail: e.vasilevskaya@fncps.ru

ORCID: https://orcid.org/0000-0002-4752-3939

* corresponding author

Anastasiya G. Akhremko - junior researcher, Experimental clinic-laboratory of biologically active substances of animal origin, V. M. Gorbatov Federal Research Center for Food Systems of Russian Academy of Sciences. 109316, Moscow, Talalikhina str., 26. Tel: +7-495-676-92-11, E-mail: a.ahremko@fncps.ru

ORCID: https://orcid.org/0000-0002-0211-8171

Ekaterina K. Polishchuk - senior laboratory assistant, Experimental clinic-laboratory of biologically active substances of animal origin, V. M. Gorbatov Federal Research Center for Food Systems of Russian Academy of Sciences. 109316, Moscow, Talalikhina str., 26. Tel.: +7-495676-92-11,E-mail: e.politchuk@fncps.ru

ORCID: https://orcid.org/0000-0003-2719-9649

Liliya V. Fedulova - candidate of technical sciences, Head of Experimental clinic-laboratory of biologically active substances of animal origin. V. M. Gorbatov Federal Research Center for Food Systems of Russian Academy of Sciences. 109316, Moscow, Talalikhina str., 26. Tel.: +7-495676-92-11, E-mail: 1.fedulova@fncps.ru

ORCID: https://orcid.org/0000-0003-3573-930X

All authors bear responsibility for the work and presented data.

All authors made an equal contribution to the work.

The authors were equally involved in writing the manuscript and bear the equal responsibility for plagiarism.

The authors declare no conflict of interest.

Received 08.08.2020 Accepted in revised 15.09.2020 Accepted for publication 25. 09.2020 